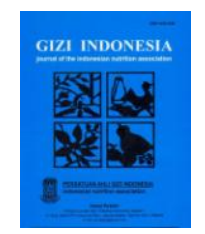

\title{
LITERATURE REVIEW: PERUBAHAN GAYA HIDUP SEBAGAI UPAYA MANAJEMEN SINDROMA METABOLIK PADA REMAJA
}

\section{Lifestyle Changes as Management of Metabolic Syndrome in Adolescents}

\author{
Rahayu Indriasari ${ }^{1}$, Yessy Kurniati ${ }^{2}$ \\ 1Program Studi IImu Gizi, Fakultas Kesehatan Masyarakat, Universitas Hasanuddin \\ ${ }^{2}$ Akademi Kebidanan Inau Makassar \\ E-mail: rindriasari@gmail.com
}

\begin{abstract}
Adolescent Metabolic syndrome began an alarming rate in accordance to the increased incidence of overweight in this population group. Given the continued impact of increased risks of degenerative diseases in adulthood, the treatment of metabolic syndrome during adolescence becomes very important to be considered. However, research related to adolescent metabolic syndrome is still very limited and there is no recommendation for its management. This unsystematic narrative review design aimed to find out the magnitude of the problem of adolescent metabolic syndrome and explored the potential of lifestyle changes as an intervention to address the problem. Narrative overview was conducted among research articles and literature review articles published within last ten years. This review found that interventions targeting lifestyle changes, such as dietary changes and changes in physical activity patterns, provide considerable opportunities to overcome metabolic syndrome in adolescents. The intervention components such as cognitive aspects, action planning, and duration were identified as keys to the success of the intervention. This review provides updated information with regards to appropriate lifestyle interventions for management of metabolic syndrome in adolescents.
\end{abstract}

Keywords: adolescent, dietary, lifestyle, metabolic syndrome, physical activity

\begin{abstract}
ABSTRAK
Masalah sindroma metabolik di kalangan remaja mulai menunjukkan angka yang mengkhawatirkan seiring dengan peningkatan kejadian obesitas pada kelompok populasi ini. Mengingat dampak lanjut dari sindroma metabolik terhadap peningkatan risiko penyakit degeneratif di usia dewasa, maka penanganan sindroma metabolik di usia remaja sangat perlu dipertimbangkan. Namun, penelitian terkait sindroma metabolik pada remaja masih sangat terbatas, terlebih lagi belum ada rekomendasi khusus untuk manajemen sindroma metabolik pada remaja. Kajian pustaka ini bertujuan untuk mengetahui besar masalah sindroma metabolik pada remaja dan menelaah potensi perubahan gaya hidup sebagai upaya intervensi yang tepat dalam menangani masalah sindroma metabolik pada remaja. Kajian secara naratif dilakukan terhadap sejumlah artikel penelitian maupun artikel kajian pustaka yang terbit dalam sepuluh tahun terakhir. Hasil kajian menunjukkan bahwa intervensi yang mentargetkan perubahan gaya hidup seperti perubahan pola makan dan perubahan pola aktifitas fisik, memberikan peluang cukup besar dalam mengatasi sindroma metabolik pada remaja. Komponen-komponen intervensi seperti aspek kognitif, perencanaan tindakan, dan durasi menjadi kunci keberhasilan intervensi. Diharapkan hasil dari kajian pustaka ini dapat memberikan informasi terkini tentang model intervensi perubahan gaya hidup sebagai upaya manajemen sindrom metabolik pada remaja.
\end{abstract}

Keywords: sindroma metabolik, remaja, gaya hidup, pola makan, aktifitas fisik 


\section{PENDAHULUAN}

D efinisi Sindrom Metabolik (SM) bervariasi tergantung pada indikator dan cut of point (nilai standar) yang digunakan dan sejauh ini belum ada keseragaman tentang kriteria yang digunakan dalam peneltian untuk menilai SM pada remaja. SM merupakan sekumpulan kelainan metabolisme yang ditandai dengan obesitas visceral, meningkatnya kadar trigliserida, glukosa darah, rendahnya kadar High Density Lipoprotein (HDL) dan hipertensi. ${ }^{1}$ Berdasarkan kriteria WHO dan European Group for the Study of Insulin Resistance, indikator SM mencakup pengukuran resistensi insulin. US National Cholesterol Education Program mengukur SM dengan mencakup ketidaknormalan pada tiga aspek yaitu kadar glukosa, trigliserida, kolesterol HDL, tekanan darah sistolik dan lingkar perut (tidak termasuk insulin). Kelishadi (2007), menggunakan kriteria untuk menentukan SM pada anak meliputi profil lipid, adipositas, dan tekanan darah. ${ }^{2}$ Sargowo, dkk (2011) menentukan SM pada remaja berdasarkan kriteria International Diabetes Federation (IDF) dengan menggunakan kriteria lingkar pinggang, kadar trigliserida dan kadar HDL. ${ }^{1}$

Deteksi awal SM pada anak yang berisiko, seperti anak yang mengalami overweight atau obesitas, sangatlah penting untuk mencegah komorbiditas obesitas di kemudian hari. Sindroma metabolik sangat berkaitan dengan obesitas karena anak dan remaja yang mengalami obesitas cenderung akan mengalami SM. Hal tersebut seperti yang dikemukakan oleh Harrel, dkk yang mengkaji tentang obesitas dan SM pada anak dan remaja, prevalensi SM pada anak yang obesitas cenderung lebih tinggi (28-49\%) dibandingkan pada anak status gizi normal (3-4\%) 3 . SM dan obesitas yang berkembang pada masa anak akan berlanjut sampai dewasa dan merupakan faktor risiko diabetes mellitus tipe 2 dan penyakit jantung koroner. Data SM pada remaja masih sangat kurang tersedia, dikarenakan jumlah penelitian yang dilakukan termasuk di Indonesia masih terbilang sedikit. Sementara kejadian overweight dan obesitas pada remaja cenderung meningkat.

Pedoman manajemen SM secara umum sejauh ini belum tersedia, namun upaya pengendalian setiap komponen SM seperti overweight, resistensi insulin, hipertensi, dan dyslipidemia telah direkomendasikan berdasarkan hasil dari sejumlah studi intervensi. Modifikasi gaya hidup seperti diet dan pola aktifitas fisik cukup efektif menurunkan risiko beberapa komponen SM tersebut ${ }^{4}$, namun penelitian lanjut masih diperlukan untuk merumuskan pedoman manajemen SM yang sesuai bagi remaja. Desain intervensi dapat dirancang berdasarkan pengetahuan yang cukup mengenai masalah SM pada remaja termasuk mengenali penyebab dan potensi penanggulangannya. Artikel ini bertujuan memberikan informasi deskriptif terkait: 1) besar masalah SM pada remaja, 2) faktor risiko pencetus SM pada remaja, 3) manajemen SM pada remaja, 4) serta komponen intervensi modifikasi gaya hidup yang mendukung keberhasilan perubahan perilaku sebagai upaya manajemen SM pada remaja.

\section{METODE PENELITIAN}

Penelusuran awal literatur dilakukan melalui mesin pencari Google Scholar dan database elektronik PubMed. Kata kunci sindroma metabolik, remaja, metabolic syndrome, dan adolescent digunakan untuk melacak artikel penelitian asli maupun kajian pustaka yang terbit dalam kurun waktu 10 tahun terakhir pada jurnal nasional maupun internasional berbahasa Inggris dan dapat diakses secara terbuka (open access). Kajian pustaka secara naratif (unsystematic narrative review) dilakukan untuk mensintesa informasi dari 28 artikel terpilih yang meneliti tentang besar masalah SM dan intervensi pada remaja.

\section{HASIL}

Hasil kajian pustaka menunjukkan masalah SM pada remaja mulai mengkhawatirkan terutama pada remaja yang overweight, sehingga memerlukan perhatian khusus untuk penanganannya. Besar masalah, faktor risiko, dan upaya penanggulangan SM remaja akan diuraikan lebih lanjut dalam bahasan.

\section{BAHASAN}

Prevalensi Sindroma Metabolik pada Remaja

Penelitian SM pada remaja masih terbatas. Kriteria dan definisi yang digunakan pun masih 
berbeda-beda. Dari sejumlah penelitian yang telah dilakukan, baik di negara maju maupun negara berkembang, menunjukkan kecenderungan terjadinya peningkatan prevalensi SM pada remaja seiring dengan meningkatnya angka kejadian overweight dan obesitas pada kelompok ini. Menurut sebuah kajian yang dilakukan oleh Harrel dkk pada tahun 20063 terhadap sekumpulan studi di USA, prevalensi SM pada penelitian berskala besar (population based) berkisar antara 3,6-4,2 persen di kalangan anak dan remaja. Sementara pada penelitian berskala kecil terutama dengan sampel overweight ditemukan prevalensi SM pada anak dan remaja overweight berkisar 28,7-39,7 persen dan remaja yang gemuk sebesar 49,7 persen. ${ }^{3}$ Ford, dkk pada tahun 2008 melaporkan bahwa dari 2014 remaja usia 12-17 tahun yang berpartisipasi dalam the National Health and Nutrition Examination Survey 1999-2004 di Amerika Serikat, terdapat prevalensi SM sebesar 4,5 persen $(6,7$ persen pada remaja putra dan 2,1 persen pada remaja putri). ${ }^{5}$ Hasil penelitian berskala nasional pada remaja di USA oleh Pan, dkk, tahun 2008 menemukan bahwa prevalensi SM 3,5 persen, lebih tinggi pada laki-laki dibandingkan perempuan $(5,1 \%$ vs $1,7 \%$ ) dan SM lebih sering ditemukan pada remaja yang overweight dibandingkan pada remaja normal. ${ }^{6}$ Fitzpatrick, dkk., yang meneliti SM pada 822 remaja ras Afro-Amerika di USA berusia 12-17 tahun melaporkan prevalensi SM sebesar 19 persen pada laki-laki dan 16 persen $\%$ pada perempuan. ${ }^{7}$ Sementara itu di Kanada, MacPherson, dkk, yang meneliti pada 1228 anak dan remaja usia 10-18 tahun menemukan prevalensi SM sebesar 2,1 persen. ${ }^{8}$ Sebuah penelitian pada 321 remaja overweight di Brasil juga menemukan 18 persen kejadian $\mathrm{SM}^{9}{ }^{9}$ Kondisi yang serupa juga ditemukan di negeranegara Eropa. Jaskelainen, dkk. (2013) yang meneliti di Finlandia tentang hubungan pola makan selama weekdays dengan kejadian overweight/obesitas dan SM pada remaja Finlandia menemukan bahwa prevalensi overweight lebih tinggi pada remaja laki-laki $(16,3 \%$ vs $13,4 \%)$ dibandingkan remaja perempuan, abdominal obesity lebih tinggi pada perempuan dibandingkan laki-laki $13,2 \%$ dan 10,1\%), SM (hiperglikemia, low HDL kolesterol, hipertensi) lebih tinggi pada laki-laki dibandingkan perempuan. ${ }^{10}$ Sebuah studi crosssectional yang dilakukan terhadap 976 anak dan remaja berusia 10-15 tahun pada sejumlah sekolah di Spanyol menemukan 3,85 persen siswi dan 5,38 persen siswa dari sampel tersebut mengalami SM. ${ }^{11}$

Kejadian SM juga ditemukan pada remaja di benua Asia. Sebuah kajian terhadap studistudi yang dilakukan pada beberapa negara berkembang di wilayah Asia, baik yang berskala besar maupun kecil, melaporkan prevalensi SM pada remaja berkisar antara 2-14 persen dan SM lebih banyak ditemukan pada remaja yang overweight dan obese. ${ }^{2}$ Di Korea Selatan, Kim, dkk (2007), yang meneliti tentang trend SM pada remaja usia 12-19 tahun menemukan terjadinya peningkatan prevalensi SM pada remaja. Tahun 1998 prevalensinya adalah 6,8 persen yang meningkat pada tahun 2001 menjadi 9,2 persen. Di Turki, Agirbasil, dkk (2006) menemukan bahwa dari 1385 remaja usia 10-17 tahun terdapat prevalensi SM sebesar 2,2 persen dan kejadian SM 10 kali lebih sering terjadi pada subjek yang menderita overweight dan obesitas dibandingkan pada subjek yang langsing. ${ }^{12}$ Di Iran, ESMailzadeh, dkk, (2006) menemukan bahwa dari 3036 remaja usia 10-19 tahun terdapat prevalensi SM sebesar 10,1 persen. $^{2}$ Di negara yang sama, Kelishadi, dkk, (2006) menemukan bahwa dari 4811 anak dan remaja usia 6-18 tahun terdapat prevalensi SM sebesar 14,1 persen. ${ }^{2}$

Gambaran ini tidak jauh berbeda dengan di Indonesia, meskipun data SM pada remaja di Indonesia masih terbilang sangat kurang dan belum ada data prevalensi SM remaja secara nasional. Penelitian yang pernah dilakukan oleh Sibarani dkk. tahun 2006 di Jakarta pada remaja Cina Indonesia yang obes menunjukkan prevalensi SM sebesar 19 persen pada laki-laki dan 10,6 persen pada perempuan. ${ }^{13}$ Mexitalia, dkk. tahun 2009 juga melakukan penelitian pada remaja gemuk maupun normal di Semarang, dengan rerata usia 13 tahun, menunjukkan prevalensi SM pada siswa gemuk adalah 31 persen sedangkan SM tidak ditemukan pada siswa normal. ${ }^{14}$ 
Tabel 1. Indikator Sindroma Metabolik yang Digunakan dalam Penelitian SM pada Remaja

\begin{tabular}{|c|c|c|c|}
\hline Indikator & Modifikasi NCEP ATP III & IDF & WHO \\
\hline $\begin{array}{l}\text { Trigliserida (mg/dl) } \\
\text { HDL (mg/dl) }\end{array}$ & $\geq 110$ & & $>150$ \\
\hline - Laki-laki & $\leq 40$ & & $<35$ \\
\hline - Perempuan & $\leq 40$ & & $<39$ \\
\hline Lingkar pinggang & & & WHR* \\
\hline - Laki-laki & $\geq$ persentil ke-90 & $\geq 90 \mathrm{~cm}$ & $>0,90$ \\
\hline - Perempuan & $\geq$ persentil ke-90 & $\geq 80 \mathrm{~cm}$ & $>0,85$ \\
\hline Glukosa darah (mg/dl) & $\geq 110$ & & $\begin{array}{l}\text { **Diabetes, intoleransi } \\
\text { glukosa, atau resistensi } \\
\text { insulin }\end{array}$ \\
\hline $\begin{array}{l}\text { Tekanan darah } \\
\text { (sistolik/diastolic) }\end{array}$ & $\geq$ persentil ke-90 & & $>140 / 90$ mmhg \\
\hline
\end{tabular}

Data dari sejumlah penelitian terdahulu menunjukkan bahwa kejadian SM pada remaja mulai memprihatinkan. Meskipun beberapa penelitian menunjukkan angka SM pada remaja yang masih rendah, namun angka yang lebih tinggi ditemukan pada remaja yang mengalami overweight maupun obesitas. Identifikasi SM sedini mungkin pada usia remaja sangat penting dilakukan mengingat besarnya risiko berkembangnya SM menjadi penyakit degeneratif lanjut seperti penyakit kardiovaskuler dan diabetes mellitus tipe 2 pada usia dewasa. SM diprediksi menyebabkan kenaikan 2 kali lipat risiko terjadinya penyakit jantung dan 5 kali lipat pada penyakit DM tipe 2.1 Penggunaan indikator yang berbeda pada setiap penelitian, mungkin mempengaruhi perbedaan prevalensi yang dilaporkan. Pacifico, dkk. (2011) yang mengkaji sejumlah studi menemukan belum ada keseragaman secara universal mengenai definisi dan kriteria penentuan SM pada anak dan remaja. ${ }^{15}$ Beberapa indikator SM remaja yang digunakan dalam penelitian-penelitian terdahulu dirangkum dalam Tabel 1.

\section{Faktor Risiko SM pada Remaja}

Penelitian terdahulu menunjukkan beberapa faktor risiko yang mencetus terjadinya SM, di antaranya yang paling utama adalah gaya hidup termasuk pola makan dan pola aktifitas fisik. Sebuah kajian terhadap beberapa studi epidemiologi gizi berskala besar, menunjukkan risiko SM meningkat dengan adanya kebiasaan konsumsi tinggi terhadap beberapa jenis makanan seperti daging, susu dan produk olahannya, serta sereal olahan (processed cereal). ${ }^{16}$ Penelitian pada remaja Indonesia menunjukkan semakin banyak asupan makan, terutama kolesterol, total kalori, diikuti dengan lemak selanjutnya karbohidrat, maka kejadian SM juga semakin meningkat. ${ }^{1}$ Penelitian juga menunjukkan keterkaitan SM dengan kualitas diet yang dikonsumsi. Seperti yang ditemukan oleh Pan, dkk. (2008) bahwa prevalensi SM pada remaja menurun sejalan dengan peningkatan skor kualitas diet dan peningkatan skor komponen sayur dan buah dalam diet. ${ }^{6}$ Penemuan tersebut mengindikasikan adanya kemungkinan hubungan antara SM dengan diet individu (kualitas diet secara umum) bila dibandingkan dengan komponen diet tertentu/spesifik. ${ }^{6} \mathrm{SM}$ juga dapat berhubungan dengan penerapan pola diet tertentu. Hyojee, dkk. pada tahun 2012 yang melakukan kajian dari beberapa studi di Korea menemukan bahwa pola diet Western berhubungan secara positif dengan resiko SM seperti obesitas dan peningkatan kadar trigliserida, dibandingkan dengan pola diet tradisional. ${ }^{17} \mathrm{Hal}$ ini dikonfirmasi dalam studi kajian yang dilakukan Weiss dkk. pada tahun 2013 yang menyimpukan bahwa pola diet Western yang diadopsi di banyak negara di berbagai belahan dunia, terutama terkait konsumsi makanan berlemak dan mengandung pemanis merupakan faktor diet yang dapat memperbesar risiko SM. ${ }^{18}$ Selain jenis asupan makanan, kualitas diet dan pola diet tertentu, frekuensi makan juga memiliki hubungan 
dengan kejadian SM pada remaja. Jaaskeleinen, dkk. pada tahun 2013 melaporkan bahwa risiko overweight/obesitas lebih rendah pada remaja yang memiliki pola makan teratur 5 kali sehari. Risiko SM lebih rendah pada remaja yang berpola makan teratur dan semi-regular, dibandingkan yang melewatkan sarapan di pagi hari. ${ }^{10}$

SM ternyata juga meningkat dengan rendahnya aktifitas fisik dan tingginya kegiatan menetap (sedentary activity). Pan, dkk. tahun $2008^{6}$ menemukan bahwa SM lebih sering ditemukan pada remaja yang tingkat aktifitas fisiknya rendah $(4,3 \%)$ dibandingkan remaja yang aktifitas sedang $(3,1 \%)$ dan tinggi $(2,6 \%)$. Mark, dkk. pada tahun $2008^{19}$ mengemukakan bahwa lamanya waktu menonton (screen time) berhubungan dengan peningkatan risiko SM pada remaja. Riwayat aktifitas fisik pada masa kanak-kanak juga berkaitan dengan risiko SM pada masa remaja. Hal ini dibuktikan oleh McMurray, dkk. (2008) yang menemukan bahwa remaja yang mengalami SM kenyataannya 6,08 kali lebih kurang melakukan senam aerobik di masa kanak-kanaknya dan 5,16 kali memiliki tingkat aktifitas fisik yang rendah di masa kanak-kanaknya. ${ }^{20}$ Tremblay, dkk, (2011) yang melakukan kajian sistematik terhadap 232 studi yang melibatkan 983.840 peserta, menemukan bahwa pengurangan jenis kegiatan sedentary apapun ternyata berhubungan dengan penurunan risiko gangguan kesehatan pada remaja usia 5-17 tahun. ${ }^{21}$

Semua penelitian yang direview tersebut melaporkan bahwa peningkatan aktivitas sedentary berhubungan dengan peningkatan risiko SM dan penyakit jantung koroner. Studi longitudinal melaporkan bahwa mereka yang menonton televisi lebih dari 2 jam per hari memiliki tingkat kolesterol serum yang tinggi dan memiliki tekanan darah yang tinggi bila dibandingkan dengan teman seusia mereka yang menonton kurang dari dua jam. ${ }^{21}$ Studi cross-sectional melaporkan bahwa waktu menonton dan aktivitas sedentary yang lama berhubungan dengan peningkatan risiko terhadap peningkatan tekanan darah sistolik dan diastolik, kadar $\mathrm{HbA} 1 \mathrm{C}$, gula darah puasa, resistensi insulin dan SM. ${ }^{21}$

Penanganan SM pada remaja mungkin dapat direkomendasikan dengan mangatasi kedua faktor risiko utama dari kejadian SM yaitu pola makan dan pola aktifitas fisik. Perubahan gaya hidup berupa modifikasi pola makan dan pola aktifitas fisik dapat menjadi salah satu alternatif manajemen SM di kalangan remaja, sekaligus dapat pula berperan sebagai salah satu upaya pencegahan dan penanganan masalah obesitas remaja maupun pencegahan penyakit degeneratif lanjut pada remaja di masa dewasanya.

\section{Manajemen SM pada Remaja}

Penelitian-penelitian sebelumnya telah melakukan berbagai intervensi perubahan gaya hidup yang secara garis besar dapat dikelompokkan ke dalam dua bagian yaitu, intervensi tunggal dalam hal ini yang dimaksud adalah melakukan intervensi perubahan pola makan (intervensi diet) saja atau perubahan pola aktifitas fisik (termasuk aktifitas sedentary) saja, dan intervensi multikomponen yaitu melakukan intervensi perubahan diet sekaligus perubahan aktifitas fisik. Berbagai model intervensi tersebut memiliki efek yang bervariasi terhadap SM pada remaja, bergantung pada indikator metabolik yang diteliti (Tabel 2).

Sejumlah penelitian berdesain eksperimental yang melakukan intervensi perubahan perilaku untuk menurunkan risiko kejadian SM pada remaja, memiliki kesamaan hasil bahwa perubahan diet, perubahan aktifitas fisik, dan perubahan aktifitas sedentary berpotensi menurunkan risiko SM sekaligus mengurangi kejadian obesitas pada remaja. Beberapa penelitian intervensi yang telah dilakukan pada remaja di negara maju menunjukkan modifikasi gaya hidup seperti intervensi diet utk mengurangi asupan kalori dan meningkatkan aktifitas fisik, cukup berhasil mengurangi obesitas sentral (sebagai salah satu komponen SM remaja) sekaligus penurunan angka obesitas secara umum serta memperbaiki profil lipid, abnormalitas glukosa, dan tekanan darah pada remaja obes. ${ }^{15}$ Penemuan dari penelitian sebelumnya juga merekomendasikan intervensi gaya hidup sehat pada remaja harus mengikutsertakan komponen yang bertujuan untuk mengurangi waktu menonton atau waktu yang dihabiskan di depan layar (televisi, komputer, game, gadget). ${ }^{19}$ 
Tabel 2. Studi Intervensi dalam Menanggulangi SM pada Remaja

\begin{tabular}{|c|c|c|c|}
\hline No & Peneliti/ desain & Intervensi & Hasil \\
\hline 1. & $\begin{array}{l}\text { Chen dkk, } 2006^{26} \\
\text { (pre-post tanpa kontrol) }\end{array}$ & $\begin{array}{l}\text { Modifikasi gaya hidup pada remaja yang } \\
\text { menajalani diet khusus dan latihan fisik aerobik }\end{array}$ & $\begin{array}{l}\text { Penurunan IMT, lingkar pinggang, dan \% lemak tubuh secara } \\
\text { signifikan Penurunan tekanan darah sistolik dan diastolik. Perbaikan } \\
\text { serum lipid secara signifikan, kecuali HDL. Kadar insulin puasa } \\
\text { menurun secara signifikan. Meskipun kadar glukosa darah puasa } \\
\text { meningkat, tetapi indikator resistensi insulin membaik. }\end{array}$ \\
\hline 2. & $\begin{array}{l}\text { Shaibi dkk, } 2006^{24} \\
\text { (randomisasi kontrol) }\end{array}$ & $\begin{array}{l}\text { Sesi training latihan ketahanan fisik selama } 16 \\
\text { minggu }\end{array}$ & $\begin{array}{l}\text { Peningkatan sensitifitas insulin pada kelompok intervensi dan } \\
\text { penurunan sensitifitas insulin pada kelompok kontrol. }\end{array}$ \\
\hline 3. & $\begin{array}{l}\text { Caranti dkk, } 2007^{27} \\
\text { (pre-post tanpa kontrol) }\end{array}$ & $\begin{array}{l}\text { Intervensi jangka panjang ( } 1 \text { tahun) dengan } \\
\text { pendekatan multi-disiplin terapi: terapi gizi } \\
\text { (anjuran mengurangi asupan maknaan dan } \\
\text { mengikuti diet seimbang), terapi latihan fisik ( } 3 \\
\text { sesi latihan per minggu, } 60 \text { menit per sesi } \\
\text { disupervisi seronag fisiologis), terapi klinis, } \\
\text { terapi psikologis. }\end{array}$ & $\begin{array}{l}\text { Prevalensi SM pd remaja mneurun. Penurunan IMT, persen lemak } \\
\text { tubuh, lemak visceral, dan peningkatan massa tubuh tanpa. } \\
\text { Penurunan signifikan terjadi pada variabel SM seperti: Tekanan darah } \\
\text { sistolik, trigliserida, total kolesterol, insulin puasa, dan HOMA-IR. }\end{array}$ \\
\hline 4. & $\begin{array}{l}\text { Singhal dkk, } 2010^{28} \\
\text { (randomisasi kontrol) }\end{array}$ & $\begin{array}{l}\text { Intervensi multikomponen: edukasi gizi, } \\
\text { edukasi aktifitas fisik, promosi gaya hidup } \\
\text { sehat, konseling individu, perubahan kebijakan } \\
\text { sekolah }\end{array}$ & $\begin{array}{l}\text { Pada kelompok intervensi terjadi penurunan rerata lingkar pinggang, } \\
\text { diameter abdominal saggital, ratio lingkar pinggang-lingkar panggul, } \\
\text { dan glukosa darah puasa, dibandingkan kelompok kontrol. }\end{array}$ \\
\hline 5. & $\begin{array}{l}\text { Jago dkk, } 2011^{30} \\
\text { (klaster randomisasi kontrol) }\end{array}$ & $\begin{array}{l}\text { Intervensi multikomponen: promosi makanan } \\
\text { sehat, perubahan perilaku kesehatan, } \\
\text { perubahan aktifitas fisik, dan komunikasi/sosial } \\
\text { marketing. }\end{array}$ & $\begin{array}{l}\text { Prevalensi SM dan komponen SM tidak berbeda secara signifikan } \\
\text { antara kelompok intervensi dan kontrol }\end{array}$ \\
\hline 6. & $\begin{array}{l}\text { Saneei dkk, } 201322 \\
\text { (randomized cross over clinical } \\
\text { trial) }\end{array}$ & $\begin{array}{l}\text { Intervensi perubahan diet: diet khusus untuk } \\
\text { hipertensi (DASH) dibandingkan dengan } \\
\text { rekomendasi diet yang biasa (UDA) }\end{array}$ & $\begin{array}{l}\text { Tidak ada perbedaan signifikan terhadap IMT, berat badan, lingkar } \\
\text { perut, dan tekanan darah sistolik pada kedua kelompok diet. Terdapat } \\
\text { perbedaan signifikan terhadap serum insulin pada kedua kelompok. }\end{array}$ \\
\hline 7. & $\begin{array}{l}\text { Bianchini dkk, } 201329 \\
\text { (non randomisasi kontrol) }\end{array}$ & $\begin{array}{l}\text { Intervensi multikomponen: terapi perilaku dan } \\
\text { psikologi, terapi gizi, latihan fisik, edukasi } \\
\text { kepada orangtua }\end{array}$ & $\begin{array}{l}\text { Efek kecil sampai moderat terhadap beberapa indikator SM, } \\
\text { dyslipidemia, dan resistensi insulin }\end{array}$ \\
\hline
\end{tabular}


Modifikasi terhadap perilaku makan (intervensi diet saja) dalam hal ini membatasi konsumsi atau asupan jenis makanan tertentu memungkinkan penurunan kejadian SM pada remaja, meskipun efeknya terbilang kecil. Hal ini dibuktikan pada penelitian Saneei, dkk. pada tahun 2013 yang meneliti tentang efektifitas intervensi diet melalui the Dietary Approaches to Stop Hypertension (DASH) eating plan terhadap remaja $S^{2}{ }^{22}$ Penelitian ini membandingkan efek dari penerapan rekomendasi perubahan diet (the DASH diet) dengan rekomendasi diet biasa (usual dietary advice-disingkat UDA) terhadap indikator sindrom metabolik dan kejadian SM pada remaja. Penelitian ini menemukan bahwa perubahan berat badan, lingkar pinggang, dan IMT tidak berbeda secara signifikan antara kedua fase diet tersebut. Meskipun perubahan tekanan darah sistolik tidak berbeda antara kedua fase diet, diet DASH terbukti mencegah peningkatan tekanan darah diastolik dibandingkan dengan diet biasa. Jika dibandingkan dengan kelompok diet biasa, kelompok diet DASH mengalami penurunan prevalensi SM dan tekanan darah tinggi, sehingga penelitian ini merekomendasikan pola diet DASH selama 6 minggu sebagai upaya penanganan SM pada remaja perempuan.

Modifikasi terhadap peningkatan aktifitas fisik cukup berpotensi untuk mengurangi risiko SM pada remaja mengingat aktitiftas fisik yang cukup dapat mencegah overweight. Sejumlah studi intervensi pada orang dewasa menunjukkan bahwa latihan fisik dapat memberikan efek kecil sampai moderat terhadap risiko SM. ${ }^{23}$

Sebuah studi intervensi pada remaja etnis Latin di USA dilakukan oleh Shaibi dkk. (2006) untuk mengamati efek latihan ketahanan fisik terhadap sensitifitas insulin, menunjukkan peningkatan sensitifitas insulin setelah 16 minggu intervensi. ${ }^{24}$ Intervensi yang bertujuan untuk mencegah perilaku sedentary yang berlebihan juga berkontribusi terhadap pencegahan overweight. Amy Van Grieken dkk. (2012) melakukan studi meta-analysis terhadap 34 studi yang memenuhi kriteria inklusi (dari 3069 studi yang dikumpulkan) menemukan bahwa dari 34 studi yang dianalisis, 13 melaporkan efek signifikan dari intervensi terhadap perilaku sedentary. ${ }^{25}$ Hasil kajian menyimpulkan tidak terdapat perbedaan signifikan pada efek terhadap perilaku sedentary antara intervensi tunggal (single behavior intervention) dengan multi-behavior. Selain itu, ditemukan pula penurunan signifikan dari perilaku sedentary sejalan dengan penurunan signifikan dari Indeks Massa Tubuh (IMT). ${ }^{25}$ Hasil analisis merekomendasikan bahwa upaya mencegah perilaku sedentary yang berlebihan merupakan salah satu pendekatan efektif untuk mewujudkan berat badan sehat pada anak dan remaja. Efek yang diperkirakan dari hasil analisis menunjukkan bahwa perilaku sedentary dan IMT tidak dipengaruhi oleh seting intervensi maupun usia anak yang menjadi target intervensi. ${ }^{25}$

Intervensi yang melibatkan pendekatan multikomponen menunjukkan hasil yang lebih signifikan dalam menangani SM di kalangan remaja. Hal ini terlihat pada penelitian oleh Chen, dkk. (2006) yang menilai efek dari program modifikasi gaya hidup pada remaja yang menjalani diet khusus dan latihan fisik aerobik, menemukan penurunan IMT, lingkar pinggang, dan persen lemak tubuh secara signifikan setelah 2 minggu intervensi, meskipun subyek penelitian masih overweight. ${ }^{26}$ Penurunan tekanan darah sistolik dan diastolik terjadi pada subyek yang terdiagnosa prahipertensi dan hipertensi pada baseline. Semua serum lipid mengalami perbaikan secara signifikan, kecuali HDL. Kadar insulin puasa menurun secara signifikan. Meskipun kadar glukosa darah puasa meningkat, tetapi indikator resistensi insulin membaik secara signifikan setelah intervensi..$^{26} \mathrm{Hal}$ yang sama ditemukan oleh Caranti dkk. pada tahun 2007 yang melakukan studi untuk menilai efek intervensi jangka panjang (1 tahun) dengan pendekatan multi-disiplin terapi terhadap prediksi SM pada remaja obes. Penelitian ini menemukan prevalensi SM pd remaja menurun dari 27,16 persen (baseline) menjadi 8,3 persen (end intervention), dan penurunan terjadi baik pada kelompok laki-laki maupun perempuan. ${ }^{27}$ Penurunan signifikan terjadi pada variabel SM seperti tekanan darah sistolik, trigliserida, total kolesterol, insulin puasa, dan HOMA-IR. Penurunan IMT, persen lemak tubuh, lemak visceral, dan peningkatan massa tubuh tanpa lemak terjadi baik pada remaja laki-laki maupun perempuan. ${ }^{27}$ Singhal, dkk. pada tahun 2010 juga membuktikan efektifitas dari model 
intervensi multi-komponen yang menerapkan edukasi gizi dan modifikasi gaya hidup terhadap perubahan perilaku, perubahan antropometri dan profil risiko metabolik pada remaja AsiaIndia di perkotaan. ${ }^{28}$ Sebuah studi intervensi di Brasil tahun 2013, memberikan multiterapi berbasis perilaku kognitif termasuk perubahan pola makan dan kebiasaan latihan atau olahraga pada 86 remaja overweight usia 10-18 tahun. ${ }^{29}$ Setelah 16 minggu intervensi, peneliti mengamati perubahan beberapa parameter SM pada kelompok intervensi sedangkan tidak ada perubahan terjadi pada kelompok kontrol. Lebih lanjut, remaja pada kelompok intervensi mengalami perbaikan pada nilai IMT, lingkar pinggang, lingkar panggul, lemak tubuh, tekanan darah, dan total kolesterol, sementara pada remaja di kelompok kontrol tidak mengalami perubahan dari parameterparameter terebut. Keberhasilan intervensi multikomponen yang ditunjukkan pada sejumlah penelitian tersebut tidak ditemukan dalam sebuah penelitian selama 3 tahun di US (the HEALTHY study). Penelitian yang menerapkan intervensi promosi makanan sehat, perubahan perilaku kesehatan, perubahan aktifitas fisik, dan komunikasi/sosial marketing tidak memberikan dampak terhadap prevalensi SM maupun komponen SM pada remaja. ${ }^{30}$

Kajian literatur yang sebelumnya telah diterbitkan menunjukkan potensi keberhasilan intervensi multikomponen untuk mengatasi SM pada remaja. Pacifico, dkk (2011) yang mengkaji sejumlah studi randomized clinical trial dan clinical trial serta meta-analisis study menyimpulkan modifikasi gaya hidup setelah intervensi diet untuk mengurangi asupan kalori dan meningkatkan aktifitas fisik cukup berhasil mengurangi obesitas sentral (pengurangan lingkar perut) sekaligus penurunan angka obesitas secara umum..$^{15}$ Mereka juga merekomendasikan perubahan diet sebaiknya memperhitungkan kelompok usia pada remaja agar tetap menyediakan asupan gizi optimal untuk mempertahankan pertumbuhan liner yang sehat dan perkembangan yang normal, seperti mengurangi asupan kalori secara moderat sambil mempertahankan diet gizi seimbang. Perubahan komposisi diet seperti membatasi atau menghilangkan konsumsi makanan jadi/olahan (processed foods), mengurangi konsumsi lemak khususnya lemak jenuh dan kolesterol, serta meningkatkan konsumsi serat pangan, dapat menjadi salah satu upaya dalam managemen dislipidemia. ${ }^{15}$ Hasil kajian tersebut juga menyimpulkan bahwa treatment utama dari dislipidemia yang berkaitan dengan SM adalah manajemen berat badan (BB) dan latihan fisik. Hasil beberapa studi yang menginvestigasi efek perubahan gaya hidup terhadap profil lipid pada remaja obes menunjukkan temuan yang bervariasi. Secara konsisten penelitian tersebut menemukan bahwa manajemen BB dan latihan fisik efektif untuk menurunkan kadar trigliserida, tetapi efeknya terhadap kadar HDL masih belum konsisten. ${ }^{15}$ Perubahan gaya hidup termasuk perubahan pola diet dan peningkatan aktivitas fisik juga menjadi upaya utama dalam penanggulangan masalah abnormalitas glukosa pada anak yang mengalami SM. Peningkatan konsumsi karbohidrat kompleks, serat pangan, buah dan sayur,serta membatasi konsumsi minuman berpemanis dilaporkan dapat memperbaiki glukosa darah pada remaja. Peningkatan aktivitas fisik juga meningkatkan pengambilan glukosa dari otot rangka dan meningkatkan metabolisme glukosa dalam tubuh serta meningkatkan resting energy expenditure. ${ }^{15}$ Perubahan diet seperti konsumsi sayur dan buah segar, serat pangan, susu rendah lemak, dan pengurangan konsumsi sodium/garam, berhubungan secara signifikan dengan penurunan tekanan darah sistolik dan diastolik. Latihan fisik menunjukkan kecenderungan memberikan efek positif terhadap kondisi hipertensi pada anak/remaja dengan SM. ${ }^{15}$ Mandy Ho dkk. pada tahun 2013 yang melakukan kajian dan meta analysis pada 23 studi randomized trial yang memenuhi kriteria inklusi (dari 6023 studi yang dikumpulkan), ternyata 12 dari 14 studi melaporkan penurunan IMT dan/atau persen lemak tubuh setelah 6 bulan intervensi, metaanalisis menunjukkan tidak ada perbedaan signifikan efek intervensi terhadap IMT dari kedua model (intervensi diet saja atau kombinasi diet dan aktivitas fisik). ${ }^{4}$ Beberapa studi menemukan bahwa peningkatan kadar $\mathrm{HDL}$, penurunan glukosa darah dan peningkatan insulin lebih besar pada intervensi yang menerapkan perubahan diet plus latihan fisik ketimbang hanya intervensi diet, sementara penurunan trigiliserida dan LDL lebih besar pada intervensi diet. Kajian ini merekomendasikan kombinasi intervensi diet dengan latihan fisik (baik aerobik maupun 
ketahanan) untuk mencapai outcome metabolik yang lebih baik. Studi intervensi sebaiknya memonitor dan melaporkan kepatuhan subjek penelitian dalam melakukan intervensi yang diterapkan (compliance) serta mengeksplor strategi untuk meningkatkan kepatuhan terhadap intervensi diet dan latihan fisik, serta meneliti efek jangka panjang dengan meningkatkan durasi follow-up. ${ }^{4}$

\section{Kompenen Keberhasilan Intervensi Gaya Hidup}

Beberapa penelitian yang melakukan intervensi untuk mengubah perilaku subjek ke arah yang lebih baik kadang tidak sepenuhnya berhasil. Hal ini disebabkan tidak terjadinya perubahan perilaku yang diinginkan terhadap subjek meskipun telah terjadi peningkatan aspek kognitif seperti pengetahuan, sikap, maupun keinginan berperilaku (behavioral intention). Beberapa literatur mengemukakan bahwa keyakinan diri (self-efficacy) sebagai salah satu aspek kognitif dapat berperan sebagai mediator antara keinginan berperilaku dengan implementasi perubahan perilaku. Demikian pula untuk terjadinya interaksi keyakinan diri dengan implementasi perilaku dalam bentuk tindakan nyata, diperlukan adanya rencana tindakan (action plan) atau yang biasa juga dikenal dengan istilah implementation planning. Oleh karena itu, intervensi yang bertujuan mengubah perilaku diet maupun aktivitas fisik termasuk aktivitas sedentary perlu mempertimbangkan upaya meningkatkan keyakinan diri dan membuat rencana aksi sebagai bagian dari komponen intervensi untuk mendukung keberhasilan terjadinya perubahan perilaku yang diinginkan.

Luszczynska dkk. (2007) melakukan studi terhadap orang dewasa usia 18-60 tahun untuk mengetahui efek intervensi self-efficacy, intervensi kombinasi self-efficacy dan action planning terhadap perubahan konsumsi buah dan sayur.$^{31}$ Penelitian ini menyimpulkan bahwa kedua model intervensi memberikan efek terhadap peningkatan konsumsi buah dan sayur pada subyek penelitan pada 6 bulan setelah intervensi berakhir. Sebaliknya tidak terjadi perubahan pada kelompok kontrol. Terjadi peningkatan self-efficacy pada kedua kelompok intervensi tetapi tidak pada kelompok kontrol. Kombinasi peningkatan self-efficacy dan action plan memberikan efek yang lebih besar terhadap peningkatan konsumsi buah sayur dibandingkan intervensi self-efficacy saja. Kreausukon, dkk. pada tahun 2010 melakukan studi di kalangan mahasiswa di universitas Thailand, melaporkan bahwa penambahan intervensi socio-cognitive (intention, selfefficacy, dan planning) meningkatkan konsumsi sayur dan buah lebih baik daripada hanya intervensi berbasis edukasi, baik dalam jangka pendek maupun jangka panjang (6-bulan follow up) self-efficacy dan planning berperan utama dalam mekanisme yang memfasilitasi perubahan diet dari subjek penelitian. ${ }^{32}$

\section{SIMPULAN DAN SARAN}

\section{Simpulan}

Sindrom metabolik pada remaja sudah harus menjadi perhatian dengan mencermati peningkatan prevalensi baik di negara maju maupun negara berkembang. Identifikasi sedini mungkin dari SM terhadap remaja perlu dilakukan karena proses pubertas yang dialami remaja dapat meningkatkan resiko SM. Sampai saat ini belum ada rekomendasi khusus dibuat sebagai pedoman manajemen SM, terlebih bagi kelompok remaja. Sebagaimana yang diindikasikan dalam sejumlah penelitian, terdapat dua faktor risiko utama pencetus SM yaitu faktor risiko gaya hidup seperti diet/pola makan yang salah, aktivitas fisik yang kurang dan aktivitas menetap yang meningkat. Sejumlah penelitian juga menunjukkan modifikasi diet, peningkatan aktivitas fisik, maupun kombinasi keduanya dapat menurunkan risiko SM pada remaja, meskipun dengan efek kecil sampai moderat. Penelitian tersebut masih terbatas dari segi desain, maupun jumlah sampel sehingga kesimpulan yang solid mengenai upaya manajemen SM pada remaja masih belum dapat dilakukan. Hal ini menandakan masih perlunya dilakukan penelitian intervensi dengan desain yang rigor untuk mengetahui efek modifikasi gaya hidup, dalam hal ini pola makan dan aktivitas fisik, terhadap kejadian SM pada remaja.

\section{Saran}

Penelitian terkait SM Remaja di Indonesia, termasuk penelitian intervensi gaya hidup dengan jumlah sampel memadai dan desain 
studi yang rigor diperlukan untuk merekomendasikan strategi penanggulangan SM pada kelompok tersebut.

\section{RUJUKAN}

1. Sargowo D, Andarini S. The relationship between food intake and adolescent metabolic syndrome. Jurnal Kardiologi Indonesia. 2011:14-23.

2. Kelishadi R. Childhood Overweight, Obesity, and the Metabolic Syndrome in Developing Countries. Epidemiologic Reviews. 2007;29(1):62-76.

3. Harrell JS, Jessup A, Greene N. Changing our future: obesity and the metabolic syndrome in children and adolescents. Journal of Cardiovascular Nursing. 2006;21(4):322-30.

4. Ho M, Garnett SP, Baur LA, et al. Impact of dietary and exercise interventions on weight change and metabolic outcomes in obese children and adolescents: A systematic review and meta-analysis of randomized trials. JAMA Pediatrics. 2013;167(8):759-68.

5. Ford ES, Li C, Zhao G, Pearson WS, Mokdad $\mathrm{AH}$. Prevalence of the Metabolic Syndrome Among U.S. Adolescents Using the Definition From the International Diabetes Federation. Diabetes Care. 2008;31(3):587-9.

6. Pan Y, Pratt CA. Metabolic syndrome and its association with diet and physical activity in US adolescents. Journal of the American Dietetic Association. 2008;108(2):276-86.

7. Fitzpatrick SL, Lai BS, Brancati FL, Golden SH, Hill-Briggs F. Metabolic Syndrome Risk Profiles Among African American Adolescents. National Health and Nutrition Examination Survey, 2003-2010. 2013;36(2):436-42.

8. MacPherson $M$, de Groh $M$, Loukine L, Prud'homme D, Dubois L. Prevalence of metabolic syndrome and its risk factors in Canadian children and adolescents: Canadian Health Measures Survey Cycle 1 (2007-2009) and Cycle 2 (2009-2011). Chronic Diseases and Injuries in Canada. 2016;36(2).

9. Rizzo AC, Goldberg TB, Silva CC, Kurokawa CS, Nunes HR, Corrente JE. Metabolic syndrome risk factors in overweight, obese, and extremely obese brazilian adolescents. Nutrition Journal. 2013;12(1):19.

10. Jääskeläinen $A, S c h w a b U$, Kolehmainen $M$, Pirkola J, Järvelin $M-R$, Laitinen J. Associations of meal frequency and breakfast with obesity and metabolic syndrome traits in adolescents of Northern Finland Birth Cohort 1986. Nutrition, Metabolism and Cardiovascular Diseases. 2013;23(10):10029.

11. González-Jiménez E, Montero-Alonso MA, Schmidt-RioValle J, García-García CJ, Padez C. Metabolic syndrome in Spanish adolescents and its association with birth weight, breastfeeding duration, maternal smoking, and maternal obesity: a crosssectional study. European Journal of Nutrition. 2015;54(4):589-97.

12. Agirbasil M, Cakir S, Ozme S, Ciliv G. Metabolic syndrome in Turkish children and adolescents. Metabolism. 2006;55.

13. Sibarani R, Rudijanto A, Dekker J, Hiene R. The Petai China Study: Metabolic Syndrome Among Obese Indonesian Chinese Adolescents. The Indonesian Journal of Internal Medicine. 2006;38:142-4.

14. Mexitalia $M$, Utari $A$, Sakundarno $M$, Yamauchi T, Subagio HW, Soemantri A. Sindroma Metabolik pada Remaja Obesitas (The metabolic syndrome among obese adolescents). Media Medika Indonesiana. 2009;43(6):300-5.

15. Pacifico L, Anania C, Martino F, Poggiogalle $E$, Chiarelli $F$, Arca M, et al. Management of metabolic syndrome in children and adolescents. Nutrition, Metabolism and Cardiovascular Diseases. 2011;21(6):455-66. 
16. Baxter AJ, Coyne T, McClintock C. Dietary patterns and metabolic syndrome-a review of epidemiologic evidence. Asia Pacific journal of clinical nutrition. 2006;15(2):134.

17. Joung $H$, Hong S, Song $Y$, Ahn BC, Park MJ. Dietary patterns and metabolic syndrome risk factors among adolescents. Korean $\mathrm{J}$ Pediatr. 2012;55(4):128-35.

18. Weiss $\mathrm{R}$, Bremer AA, Lustig RH. What is metabolic syndrome, and why are children getting it? Annals of the New York Academy of Sciences. 2013;1281(1):123-40.

19. Mark AE, Janssen I. Relationship between screen time and metabolic syndrome in adolescents. Journal of Public Health. 2008;30(2):153-60.

20. McMurray R, Bangdiwala $S$, Harrell J, Amorim L. Adolescents with metabolic syndrome have a history of low aerobic fitness and physical activity levels. Dynamic Medicine. 2008;7(1):5.

21. Tremblay M, LeBlanc A, Kho M, Saunders $T$, Larouche R, Colley R, et al. Systematic review of sedentary behaviour and health indicators in school-aged children and youth. International Journal of Behavioral Nutrition and Physical Activity. 2011;8(1):98.

22. Saneei $P$, Hashemipour M, Kelishadi R, Rajaei $S$, Esmaillzadeh A. Effects of recommendations to follow the Dietary Approaches to Stop Hypertension (DASH) diet v. usual dietary advice on childhood metabolic syndrome: a randomised crossover clinical trial. British Journal of Nutrition. 2013;110(12):2250-9.

23. Lakka TA, Laaksonen DE. Physical activity in prevention and treatment of the metabolic syndrome. Applied Physiology, Nutrition, and Metabolism. 2007;32(1):76-88.

24. Shaibi GQ, Cruz ML, Ball GD, Weigensberg MJ, Salem GJ, Crespo NC, et al. Effects of resistance training on insulin sensitivity in overweight Latino adolescent males. Medicine and science in sports and exercise. 2006;38(7):1208.
25. van Grieken A, Ezendam N, Paulis W, van der Wouden J, Raat H. Primary prevention of overweight in children and adolescents: a meta-analysis of the effectiveness of interventions aiming to decrease sedentary behaviour. International Journal of Behavioral Nutrition and Physical Activity. 2012;9(1):61.

26. Chen AK, Roberts CK, Barnard RJ. Effect of a short-term diet and exercise intervention on metabolic syndrome in overweight children. Metabolism. 2006;55(7):871-8.

27. Caranti DA, de Mello MT, Prado WL, Tock L, Siqueira KO, de Piano A, et al. Short-and long-term beneficial effects of a multidisciplinary therapy for the control of metabolic syndrome in obese adolescents. Metabolism. 2007;56(9):1293-300.

28. Singhal N, Misra A, Shah P, Gulati S. Effects of controlled school-based multicomponent model of nutrition and lifestyle interventions on behavior modification, anthropometry and metabolic risk profile of urban Asian Indian adolescents in North India. Eur J Clin Nutr. 2010;64(4):364-73.

29. Bianchini JAA, da Silva DF, Nardo CCS, Carolino IDR, Hernandes F, Junior NN. Multidisciplinary therapy reduces risk factors for metabolic syndrome in obese adolescents. European Journal of Pediatrics. 2013;172(2):215-21.

30. Jago R, Mcmurray RG, Drews KL, Moe EL, Murray $\mathrm{T}$, Pham TH, et al. HEALTHY intervention: fitness, physical activity, and metabolic syndrome results. Medicine and science in sports and exercise. 2011;43(8):1513.

31. Luszczynska A, Tryburcy M, Schwarzer R. Improving fruit and vegetable consumption: a self-efficacy intervention compared with a combined self-efficacy and planning intervention. Health Education Research. 2007;22(5):630-8.

32. Kreausukon $P$, Gellert $P$, Lippke $S$, Schwarzer R. Planning and self-efficacy can increase fruit and vegetable consumption: a 
randomized controlled trial. Journal of behavioral medicine. 2012;35(4):443-51. 